\title{
FORMULATION OF MATHEMATICAL PROBLEM DESCRIBING PHYSICAL AND CHEMICAL PROCESSES AT CONCRETE CORROSION
}

\author{
Sergey V. Fedosov, Varvara E. Roumyantseva, Igor V. Krasilnikov, \\ Boris E. Narmania \\ Ivanovo State Politechnical University, Ivanovo, RUSSIA
}

\begin{abstract}
The article deals with the relevance of new scientific research focused on modeling of physical and chemical processes occurring in the cement concrete at their exploitation. The basic types of concrete corrosion are described. The problem of mass transfer processes in a flat reinforced concrete wall at concrete corrosion of the first and the second types has been mathematically formulated.
\end{abstract}

Keywords: cement concrete, concentration of calcium hydroxide, corrosion, mass transfer, liquid environment, mass conductivity, mass output

\section{ПОСТАНОВКА МАТЕМАТИЧЕСКОЙ ЗАДАЧИ ОПИСАНИЯ ФИЗИЧЕСКИХ И ХИМИЧЕСКИХ ПРОЦЕССОВ ПРИ КОРРОЗИИ БЕТОНА}

\author{
С.В. Федосов, В.Е. Румянцева, И.В. Красильников, Б.Е. Нармания \\ Ивановский государственный политехнический университет, г. Иваново, РОССИЯ
}

\begin{abstract}
Аннотация: В настоящей статье отмечается актуальность новых научных исследований, ориентированных на моделирование физических и химических процессов, происходящих в бетоне на цементе в условиях эксплуатации. Рассмотрены и описаны основные типы коррозии бетона. Математически сформулирована проблема процессов массопереноса в плоской железобетонной стене в условиях коррозии бетона первого и второго типов.
\end{abstract}

Ключевые слова: бетон на цементе, концентрация гидроксида кальция, коррозия, массоперенос, жидкая среда, массовая проводимость, массовая выработка

Concrete is a building material known to man from the depth of centuries at the turn of the third and fourth millennia $\mathrm{BC}$, swiftly broke into the 19th century and was named by the contemporaries the building material of the 20th century. And in the beginning of the 21-st century it remains the most popular material for construction of unique structures and typical buildings for industrial and civil purposes [1].

However, as a man-made synthetic composite, concrete (reinforced concrete) remains the subject of close attention of researchers. And along with the solution of technological problems of creating and life cycle of exploitation of reinforced concrete structures, researchers' attention to the problem of the durability of concrete persists. Carrying out of such researches will preserve unique building structures for future generations, ensure the safety of human life activity, as well as save a lot of money for national economy.

Predicting the durability of construction is rather complex analytical process, requiring diverse system knowledge of several sciences: physical chemistry, electrochemistry, thermodynamics, theory and kinetics of heterogeneous chemical processes, mass transfer in capillary-porous bodies [2].

For 150 years of studying corrosion destruction processes of concrete scientists have 
accumulated a large amount of scientific knowledge about corrosion processes in concrete and reinforced concrete: basic schemes of chemical reactions have been identified and studied; mathematical description of certain corrosion processes has been given; a system of normative documents regulating corrosion in the construction industry has been created.

The cumulative theoretical and practical material makes it possible to describe concrete corrosion processes in the form of mathematical models that allow calculating with the required accuracy the durability of concrete and reinforced concrete structures.

According to generally classification proposed by Professor V.M. Moskvin [3], corrosive effects of any environment on concrete is divided into three main types:

- corrosion of the 1st type includes processes that occur in concrete under the influence of low hardness water when the components of cement stone are dissolved, washed out and carried away by moving water environment;

- corrosion of the 2 nd type includes processes that develop in concrete when exposed to liquids containing chemical substances that come into exchange reactions with components of cement stone to form easily water-soluble products or amorphous, non-binding mass in reaction zone;

- corrosion of the $3 d$ type includes all the processes of concrete corrosion under the influence of liquid aggressive environment, the development of which results in accumulation in pores, capillaries and other concrete voids of poorly soluble salts, crystallization of which gives rise to considerable stress in cement stone structure, limiting the growth of crystal formations.

It should be noted that corrosion of any type is rarely found in nature separately from the others, but usually one type is predominant and it is always possible to trace and consider the role of the secondary in this case types of corrosion.

It is known that the stability of highly basic compounds of concrete (alite, belite, tricalcium aluminate, tetracalcium alumoferrite) is due to contained in concrete pores «free calcium hydroxide», so it would be logical to predict the service life of product in terms of its amount in the body structure [4].

Herewith in terms of heat and mass transfer theory $[5,6]$ transfer of calcium hydroxide occurs in three stages:

- mass conductivity (diffusion) of calcium hydroxide from the inner layers of concrete to «concrete - liquid» phase boundary;

- mass transfer through the phase boundary;

- mass transfer from the phase boundary to the volume of liquid medium.

The simulated system is schematically shown in Figure 1, which also shows characteristic profiles of transferred component concentrations in concrete (dynamics of mass transfer in solid phase) and component concentration change in liquid phase (kinetics of mass transfer).

According to the theory of mass transfer of academician Lykov A.V. [6,7], in general, for corrosion of the first and second types, calcium hydroxide diffusion in the porous structure of concrete is described by the nonlinear second order mass transfer equation:

$$
\begin{aligned}
& \frac{\partial C(x, \tau)}{\partial \tau}= \\
& =\operatorname{div}[k(x, \tau) \operatorname{grad} C(x, \tau)]+q_{v}(x, \tau) / \rho_{\text {concrete }}
\end{aligned}
$$

in which: $k(x, \tau)-$ coefficient of mass conductivity (diffusion), $\mathrm{m}^{2} / \mathrm{s} ; C(x, \tau)-$ concentration of «free calcium hydroxide» in concrete at time $\tau$ at an arbitrary point with coordinate $\mathrm{x}$, $\mathrm{kg} \mathrm{CaO} / \mathrm{kg}$ of concrete; $q_{v}(x, \tau)$ - power of volume source of mass due to chemical or phase transformations, $\mathrm{kg} \mathrm{CaO} /\left(\mathrm{m}^{3} \cdot \mathrm{s}\right) ; \rho$ concrete - density of concrete, $\mathrm{kg} / \mathrm{m}^{3}$.

To obtain a correct solution of equation (1), it must be supplemented with initial and boundary conditions. 

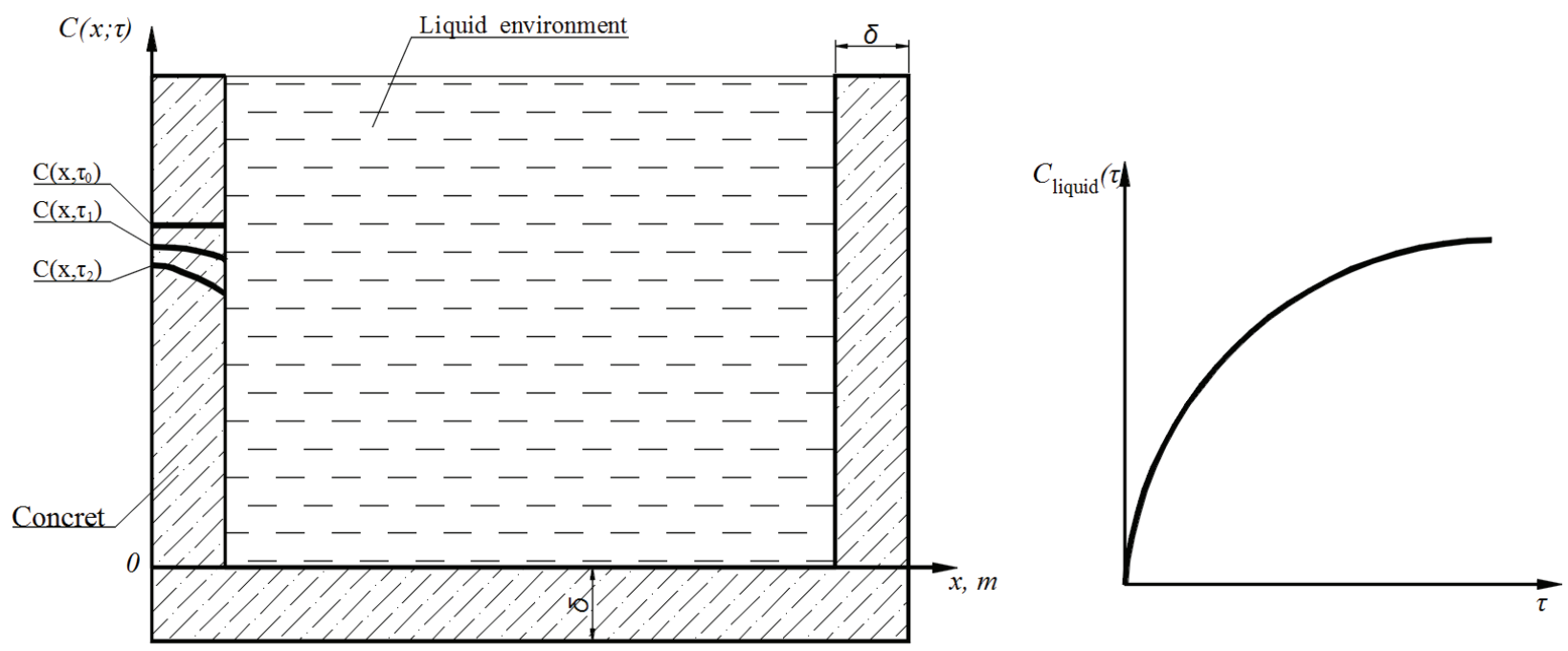

Figure 1. Scheme of liquid storage tank with characteristic profiles of transferred component concentrations in concrete and in liquid phase.

Initial distribution of «free calcium hydroxide» concentrations through the thickness of concrete wall $\mathrm{C} 0(\mathrm{x})$ is assumed to be uniform:

$$
\left.C(x, \tau)\right|_{\tau=0}=C(x, 0)=C_{0}(x) .
$$

Considering the fact that there is no substance flow at the left boundary of concrete wall, we write down the boundary condition at the point with the coordinate $\mathrm{x}=0$ :

$$
\frac{\partial C(0, \tau)}{\partial x}=0
$$

To describe the regularity of concrete and liquid interaction process on the surface of phase boundary, i.e. on the right side of the concrete wall, we assume that the amount of «free calcium hydroxide» supplied from the inner layers of concrete to its surface due to mass conductivity is equal to the amount of substance diverted from the surface of the body to the outer phase by means of convective diffusion:

$$
\begin{aligned}
& \rho_{\text {concrete }} k \frac{\partial C(\delta, \tau)}{\partial x}= \\
& \quad=\beta_{c}\left[C_{n \text { liquid }}(\tau)-C_{\text {liquid }}(\tau)\right] \rho_{\text {liquid }} .
\end{aligned}
$$

in which: $\beta_{c}-$ coefficient of mass transfer in liquid medium, $\mathrm{m} / \mathrm{s} ; \quad C_{n}$ liquid $(\tau), C_{\text {liquid }}(\tau)-$ concentration of calcium hydroxide in the liquid near the surface of phase boundary and in stream core, respectively, at time $\tau$, in terms of $\mathrm{CaO}, \mathrm{kg} \mathrm{CaO} / \mathrm{kg}$ of liquid; $\rho_{\text {concrete, }} \rho_{\text {liquid }}$ density of concrete and water, $\mathrm{kg} / \mathrm{m}^{3}$.

Expression (4) is a boundary condition of the third type, its mathematical notation can be modified by assuming that concentration of calcium hydroxide varies proportionally in the liquid near the surface phase boundary, in stream core, as well as in concrete body at phase boundary. For this we apply the approach proposed in [8]:

$$
\begin{gathered}
\rho_{\text {concrete }} k \frac{\partial C(\delta, \tau)}{\partial x}=\beta_{c} \rho_{\text {concrete }}\left[C_{p}(\tau)-C(\delta, \tau)\right] \\
\rho_{\text {liquid }} \frac{\left[C_{n \text { liquid }}(\tau)-C_{\text {liquid }}(\tau)\right]}{\rho_{\text {concrete }}\left[C_{p}(\tau)-C(\delta, \tau)\right]} \cdot \text { (5) }
\end{gathered}
$$

having designated:

$$
\beta^{*}=\frac{\rho_{\text {liquid }}\left[C_{n \text { liquid }}(\tau)-C_{\text {ж) }}(\tau)\right]}{\rho_{\text {concrere }}\left[C_{p}(\tau)-C(\delta, \tau)\right]},
$$


we obtain a modified form of the third type boundary condition:

$$
k \frac{\partial C(\delta, \tau)}{\partial x}=\beta^{*}\left[C_{\text {subjected }}(\tau)-C(\delta, \tau)\right] .
$$

here: $C_{\text {subjected }}(\tau)$ - is the equilibrium concentration of the transferred component on the surface of a solid body, $\mathrm{kg} \mathrm{CaO} / \mathrm{kg}$ of concrete; $\beta^{*}$ the modified mass transfer coefficient in a liquid medium, $\mathrm{m} / \mathrm{s}$.

The balance of transferred component mass («free calcium hydroxide») between the solid and liquid phases is determined by the relation [8]:

$$
-S \cdot \rho_{\text {concrete }} \cdot k \cdot \frac{\partial C(\delta, \tau)}{\partial x}=V_{\text {liquid }} \cdot \rho_{\text {liquid }} \cdot \frac{\partial C_{\text {liquid }}(\tau)}{\partial \tau} .
$$

In this equation, the left part is the amount of the transferred component through the inner surface of the tank $S, \mathrm{~m}^{2}$ per unit of time; the right part is the mass increment of the component in the liquid volume $V_{\text {liquid }}$ of the reservoir, $\mathrm{m} 3$ per unit of time; $C_{\text {liquid }}(\tau)$ is the concentration of calcium hydroxide in the liquid at time $\tau$, in terms of $\mathrm{CaO}, \mathrm{kg} \mathrm{CaO} / \mathrm{kg}$ of liquid; $\rho$ concrete, $\rho$ liquid - density of concrete and liquid, respectively, $\mathrm{kg} / \mathrm{m}^{3}$. The «-» sign indicates decrease in the hydroxide calcium concentration in concrete.

Up to a certain «bound» concentration of $C_{\text {liquid }}$, the equilibrium is subjected to Henry's linear law:

$$
C_{\text {subjected }}(\tau)=m C_{\text {liquid }}(\tau)
$$

in which: $\mathrm{m}$ is Henry's equilibrium constant, $\mathrm{kg}$ of liquid / $\mathrm{kg}$ of concrete.

Thus, the formulated above system of differential equations of mass transfer, together with the initial and boundary conditions, is a mathematical model of the real process of mass transfer during cement concrete corrosion of the first type for a closed "liquid-tank" system. The solu- tion of this system allows to obtain a complete picture of the distribution of substance in time and to analyze the kinetics and dynamics of the process.

\section{REFERENCES}

1. Nikolaev S.V., Travush V.I., Tabunshchikov Yu.A., Kolubkov A.N., Solomanidin G.G., Magay A.A., Dubynin N.V. Normativnaja baza vysotnogo stroitel'stva v Rossii [Regulatory Framework of high-rise construction in Russia]. Zhilishchnoe Stroitel'stvo, 2016, No. 1-2, pp. 3-7.

2. Stepanova V.F., Rosental N.K. Zashhita ot korrozii v uslovijah nehvatki finansirovanija nauki [Protection against corrosion in the conditions of science financing shortage]. Stroitel'naya Gazeta, 2013, No. 19 (10238), pp. 1,3.

3. Moskvin V.M. Korrozija betona [Corrosion of concrete]. Moscow, Gosstroiizdat, 1952, $344 \mathrm{p}$.

4. Mchedlov-Petrosyan O.P. Himija neorganicheskih stroitel'nyh materialov [Chemistry of inorganic building materials]. Moscow, Stroyizdat, 1988, 303 p.

5. Fedosov S.V. Teplomassoperenos v tehnologicheskih processah $\mathrm{v}$ stroitel'noj otrasli [Heat and mass transfer in technological processes in construction industry]. Ivanovo, IPC PresSto, 2010, 364 p.

6. Lykov A.V., Mikhailov Yu.A. Teorija teplomassoperenosa [Theory of heat and mass transfer]. Moscow, Leningrad, Gosenergoizdat, 1963, $536 \mathrm{p}$.

7. Lykov A.V. Javlenija perenosa v kapilljarno-poristyh telah [Phenomena of transfer in capillary-porous bodies]. Moscow, Gostekhizdat, 1954, 296 p.

8. Akselrud G.A., Lysyansky V.M. Jekstragirovanie. Sistema tverdoe telo - zhidkost' [Extraction (solid-liquid system)]. Moscow, Himija, 1974, 256 p.

9. Rudobashta S.P. Massoperenos v sistemah 
s tvjordoj fazoj [Mass transfer in systems with solid phase]. Moscow, Himija, 1980, $248 \mathrm{p}$.

Sergey V. Fedosov, Full Member of the Russian Academy of Architecture and Construction Sciences, Professor, DSc, President of Ivanovo State Politechnical University; 20, ul. 8 Marta, Ivanovo, 153037, Russia; tel. +7(4932) 32-97-55; e-mail:prezident@ivgpu.com.

Varvara E. Roumyantseva, Advisor of the Russian Academy of Architecture and Construction Sciences, Professor, DSc, Director of the Institute of Social and Humanitarian and Natural Sciences, Ivanovo State Politechnical University; 20, ul. 8 Marta, Ivanovo, 153037, Russia; tel. +7(4932) 41-75-09; e-mail: yzsgen@ivgpu.com.

Igor V. Krasilnikov, Associate Professor, Ph.D., Head of the Center for Scientific Research and Technical Expertise in Construction, Ivanovo State Politechnical University; 20, ul. 8 Marta, Ivanovo, 153037, Russia;

tel. +7(4932) 38-01-81, 37-34-14;

e-mail: kc037@mail.ru.

Boris E. Narmania, Student, Ivanovo State Politechnical University; 20, ul. 8 Marta, Ivanovo, 153037, Russia; tel. +7(4932) 32-85-40; e-mail: yzsgen@ivgpu.com.

Федосов Сергей Викторович, академик РАACH, профессор, доктор технических наук, президент Ивановского государственного политехнического университета; 153037, Россия, г. Иваново, ул. 8 Марта, д. 20; тел. +7(4932) 32-97-55; e-mail:prezident@ivgpu.com.

Румянцева Варвара Евгеньевна, советник РААСН, профессор, доктор технических наук, директор Института социально-гуманитарных и естественных наук, Ивановский государственный политехнический университет; 153037, Россия, г. Иваново, ул. 8 Марта, д. 20; тел. +7(4932)32-97-55;

e-mail: yzsgen@ivgpu.com.

Красильников Игорь Викторович, доцент, кандидат технических наук, руководитель Центра научноисследовательских работ и технической экспертизы в строительстве, Ивановский государственный политехнический университет; 153037, Россия, г. Иваново, ул. 8 Марта, д. 20; тел. +7(4932) 38-01-81, 37-34-14; e-mail:kc037@mail.ru.

Нармания Борис Евгеньевич, студент, Ивановский государственный политехнический университет; 153037, Россия, г. Иваново, ул. 8 Марта, д. 20; тел. +7(4932) 32-85-40; e-mail: yzsgen@ivgpu.com. 